\title{
Competence Making on Computer Engineering Program by Using Analytical Hierarchy Process (AHP)
}

\author{
Ahmad Yani \\ Academy of Information Management and Computer \\ AMIKOM Mataram \\ Mataram, Indonesia
}

\author{
Lalu Darmawan Bakti \\ Academy of Information Management and Computer \\ AMIKOM Mataram \\ Mataram, Indonesia
}

\begin{abstract}
This paper shows competence election for the students of the Academy of Information Management and Computer (AIMC) Mataram on computer engineering courses who completed the study in semester 1, 2 and 3 and choose lesson competence. The competence election on computer engineering courses is intended to make students get easier in choosing the appropriate competence and professional expertise of students in an effort to steer students to the ability and the students' academic achievement. It is an uneasy thing for the students. Limited information make the students find it difficult to choose the competence of determining the best based on the academic achievement and interest. To solve the problems, standard decision support system is required to help and provide a solution or an alternative based on the accurate data by using Analytical Hierarchy Process (AHP) that is computerized.
\end{abstract}

Keywords-Decision Support System; AHP; Competence; Criteria

\section{INTRODUCTION}

Everyone is often faced with a situation that is very frustrating and confusing, so everyone find it difficult to determine the choice of several options. A problem can be resolved in various ways, solutions or alternatives in problemsolving [8].

Academy of Information Management and Computer students at engineering study program who complete his or her study in semester 1,2 and 3 choose the competence. It is intended to make students more easily in determining the appropriate competence and professional expertise of students to steer students to the ability and the students' academic achievement. It is uneasy to choose the competence because of the limited information. So, it is hard for them to choose it based on his or her interest.

Competence election is usually determined by three factors. The first is based on the parents. The second is based on the tradition. The third factor is the academic achievement of the students. Competence determination by these three factors will certainly make regret for the students concerned because they do not correspond to their talents, interests, and their profession[4].

To solve the problems, it is needed a standard decision support system that can help and provide a solution or the best alternative to solve problems effectively and efficiently based on factual data. Therefore, this study only focuses on the competence election on system engineering informatics courses using Analytical Hierarchy Process (AHP)[5].

\section{REVIEW OF RELATED LITERATURE}

\section{A. Decision Support System}

Decision support system is an interactive information system that provides information, modeling, and manipulation of data. It was first introduced in the early 1970s by Michael S. Scott Morton with the terms Decision Management System. The concept of decision support is characterized by a computer-based interactive system that helps decision-making, utilize data and models to solve problems that are not structured [5].

\section{B. Hierarchy Analytical Process (AHP)}

Hierarchy Analytical Process (AHP) is a functional hierarchy that helps to be better in making the decision on issues that have a lot of objectives. Another goal of the AHP approach is to equip a framework and techniques rank viable alternatives based on decision making [1].

AHP is a decision support models developed by Thomas L. Saaty. It will outline the multi-factor problem or a complex multi-criterion into a hierarchy. According to Saaty, hierarchy is a representative of a complex problem in a multi-level structure and it is the first multi -level goal. It also followed the level of factors, criteria, sub-criteria, and the last of alternatives level. By using the hierarchy, a complex problem can be described in their groups were then organized into a hierarchical form so that the problem would appear more structured and systematic. AHP is often used as a method of solving the problem compared to other methods because of the following reasons[8]:

- The hierarchical structure as a consequence of the criteria chosen to the deepest sub-criteria.

- Taking into account validation until the limit of tolerance inconsistencies various criteria and alternatives are selected by decision makers.

- Taking into account the durability of the sensitivity analysis output decision. 
AHP was designed to reflect the way people think. This method enables the quantitative and qualitative aspects of the decision that will be taken into consideration. AHP reduces complex decisions into a series of one -on-one comparison that then gives accurate results. It also uses a scale to weight ratio and scoring criteria alternative that adds to the measurement precision [5].

\section{Phase AHP Method}

This study was done by using Process Analytical Hierarchy in making the decision. The stages in the method of AHP were as follows [11][9][8]:

1) Define the problem and determine the desired solution. In this phase, the problems that faced is choosing the best competence based on the academic achievement of certain courses, ability test competence, and students' interests to get the right decision.

2) Make a hierarchical structure that begins with the main goal. The main destination is located on the top level, followed by the level of hierarchy and alternative.

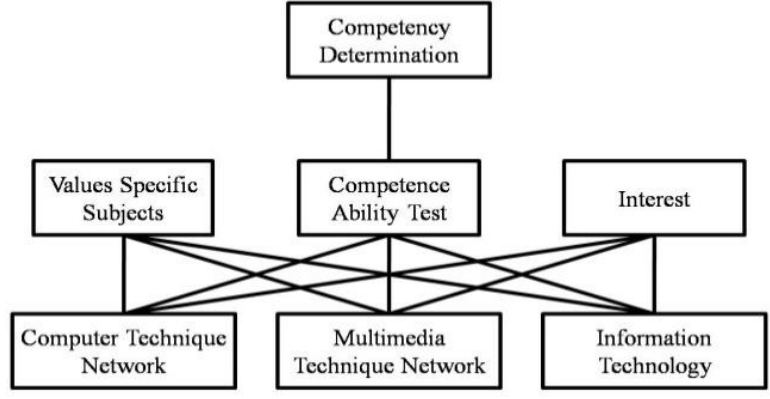

Fig. 1. Structure AHP

3) Make the pairwise comparison matrix that describes the contribution of a relative or influence each element of the destination or the equivalent criteria above. Comparisons are made based on judgment of decision makers to judge the importance of an element. Whereas the importance of the elements of the other elements are as follows:

a) Subjects specific criteria Value 4 times more important than interest, and three times more important than competence Ability Test.

b) Competence Ability Test Criteria 2 times more important than interest.

TABLE I. PAIRWISE COMPARISON

\begin{tabular}{|c|c|c|c|}
\hline $\begin{array}{c}\text { Criteria } \\
\bullet\end{array}$ & $\begin{array}{c}\text { Values Specific } \\
\text { Subjects }\end{array}$ & $\begin{array}{c}\text { Competence } \\
\text { Ability Test }\end{array}$ & $\begin{array}{c}\text { Interest } \\
\bullet\end{array}$ \\
\hline $\begin{array}{c}\text { Values } \\
\text { Specific } \\
\text { Subjects }\end{array}$ & $\bullet 1$ & $\bullet 3$ & $\bullet 4$ \\
\hline $\begin{array}{c}\text { Competence } \\
\text { Ability Test }\end{array}$ & $\bullet 1 / 3$ & $\bullet 1$ & $\bullet 2$ \\
\hline Interest & $\bullet 1 / 4$ & $\bullet 1 / 2$ & $\bullet 1$ \\
\hline
\end{tabular}

4) Performing pairwise comparisons in order to obtain the number of votes as much entirely $n x[(n-1) / 2$ ]. Where $n$ is the number of elements relevant to the comparison. The comparison of each element will be a number from 1 to 9 which shows a comparison of interests of an element.

TABLE II. BASIC SCALE PAIRWISE COMPARISON

\begin{tabular}{|c|c|c|}
\hline Values & Definition & Details \\
\hline 1 & Equally Important & $\begin{array}{l}\text { Both elements have the same } \\
\text { effect }\end{array}$ \\
\hline 3 & $\begin{array}{l}\text { Slightly More } \\
\text { mportant }\end{array}$ & $\begin{array}{l}\text { Experience and judgment so } \\
\text { favoring one element compared to } \\
\text { her partner }\end{array}$ \\
\hline 5 & More Important & $\begin{array}{l}\text { One element is preferred and } \\
\text { practically very real domination, } \\
\text { compared with elements of } \\
\text { partner. }\end{array}$ \\
\hline 7 & Very Important & $\begin{array}{l}\text { One element proved to be well- } \\
\text { liked and very real practical } \\
\text { domination, compared with } \\
\text { elements of partner. }\end{array}$ \\
\hline 9 & $\begin{array}{l}\text { Absolutely More } \\
\text { Important }\end{array}$ & $\begin{array}{l}\text { One element of absolute proven } \\
\text { preferable to his partner, the } \\
\text { highest confidence. }\end{array}$ \\
\hline $2,4,6,8$ & Median & $\begin{array}{l}\text { Given if there is any doubt in the } \\
\text { ratings between the two levels of } \\
\text { interest nearby }\end{array}$ \\
\hline Reverse & \multicolumn{2}{|c|}{$\begin{array}{l}\text { If activity } \mathrm{i} \text { got a figure compared to activity } \mathrm{j} \text {, then } \mathrm{j} \\
\text { has the opposite value compared with } \mathrm{i}\end{array}$} \\
\hline
\end{tabular}

5) Calculate the eigen values and test consistency. If not consistent then the decision may be repeated.

6) Repeat steps 3, 4 and 5 for all levels of hierarchy.

7) Calculating the eigenvectors of each pairwise comparison matrix that is the weight of each element for the determination of priority elements at the lowest level of the hierarchy until it reaches the destination.

8) Check the consistency of the hierarchy. As measured in Hierarchy Analytical Process is the ratio of consistency with seeing the consistency index. Consistency is expected that close to perfect in order to produce a valid decision approached. Consistency ratio expected to be less than $10 \%$.

9) Berordo consistency index of the matrix $n$ can be obtained by the following formula:

$$
C I=\frac{\varphi \text { maksimum }-n}{n-1}
$$

The formula in determining the consistency ratio (CR)

$$
C R=\frac{C R}{R I}
$$

TABLE III. VALUE INDEX RANDOM CONSISTENCY FOR COMPARISON N CATEGORY

\begin{tabular}{|l|l|l|l|l|l|l|l|l|l|}
\hline $\mathbf{N}$ & 1 & 2 & 3 & 4 & 5 & 6 & 7 & 8 & 9 \\
\hline $\mathbf{R I}$ & 0 & 0 & 0.58 & 0.9 & 1.12 & 1.24 & 1,32 & 1.41 & 1.45 \\
\hline
\end{tabular}

\section{Competence}

Competence is the skill or expertise that is owned by someone in the running or doing some field work according to their talents and interests. To achieve a certain competence, one needs to have a number of capabilities. Capability is 
usually a combination of a personal nature dimensions, skills and knowledge. There are five types of basic characteristics on competence, namely [4]:

- Motif is something which continually thought or wanted by someone who causes the action.

- Nature is a physical characteristics and consistent response to the situation and information.

- The concept of personal (Self Concept), namely behavioral values and personal impressions of a person.

- Knowledge is information regarding a person who has a certain substance field.

- Skill is the ability to perform certain physical and mental tasks.

\section{RESEARCH METHOD}

\section{A. Types of Research}

This study belongs to a qualitative research, because it tests the hypotheses by using statistical techniques. The statistical data obtained from the weighted value of certain subjects obtained by students in semester 1, 2 and 3, tests the ability of competence and interests of students using Hierarchy Process Analytical method and then tested with the Expert Choise 11 software [5].

\section{B. Data Collecting Techniques}

Data collecting techniques was conducted by collecting the students' paper score of the and performing weighting on three courses the student competence by giving the value of the sub criteria of competence (Very Good for grades 3-4, Good for the value of 2- Quite to the value of 2.9 and 1-1.9) and the value for each weighting is 1 to Very Good, 2 and 3 for Good Enough.

We gave a test with 10 questions that consisted of three for network computer technique, three for network multimedia technique, and three for Information technology and one for general question.

The data was collected after the students conducted the test. The scores were grouped based on the competence problems that exist with the sub-criteria assessment of the results obtained by the students (Very Good for grades 3-4, Good for the value of 2-2.9 and 1-1.9 Enough to value) and value for each weighting is 1 to Very Good, 2 for Good and 3 for Undecided.

Giving questionnaire based on the students' interest by circling the numbers which indicated on each competency with the provisions of sub-criteria (1 to choice Interests First, 2 For option Interest Second, and Third Interests 3 for selection).

Collecting questionnaires that were filled by the students and categorized it into some category options 1,2 and 3 .

\section{FINDING AND DISCUSSION}

\section{A. Design System}

Decision-making system design using Hierarchy Process Analytical method shown in Figure 2

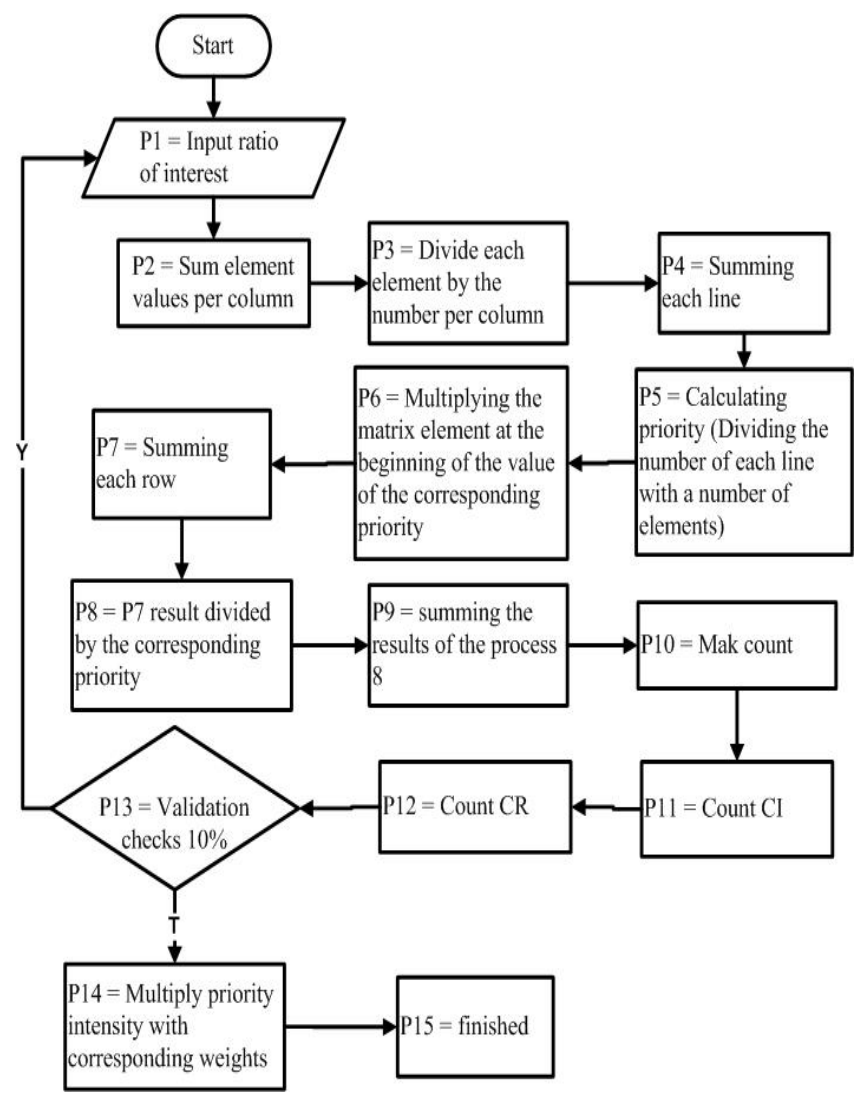

Fig. 2. Flowchart AHP

\section{B. Discussion}

1) Changing the comparison matrix in table 1 into decimal and elements scores.

TABLE IV. COMPARISON MATRIX FORM DECIMAL

\begin{tabular}{|c|c|c|c|}
\hline Criteria & $\begin{array}{c}\text { Values Specific } \\
\text { Subjects }\end{array}$ & $\begin{array}{c}\text { Competence } \\
\text { Ability Test }\end{array}$ & Interest \\
\hline $\begin{array}{c}\text { Values Specific } \\
\text { Subjects }\end{array}$ & 1,000 & 3,000 & 4,000 \\
\hline $\begin{array}{c}\text { Competence } \\
\text { Ability Test }\end{array}$ & 0,333 & 1,000 & 2,000 \\
\hline Interest & 0,250 & 0,500 & 1,000 \\
\hline Sum & 1,583 & 4,500 & 7,000 \\
\hline
\end{tabular}

2) Dividing each element of the column with the number of the column in question. 
TABLE V. DISTRIBUTION OF ELEMENTS EACH COLUMN

\begin{tabular}{|c|c|c|c|}
\hline Criteria & $\begin{array}{c}\text { Values Specific } \\
\text { Subjects }\end{array}$ & $\begin{array}{c}\text { Competence } \\
\text { Ability Test }\end{array}$ & Interest \\
\hline $\begin{array}{c}\text { Values Specific } \\
\text { Subjects }\end{array}$ & 0.632 & 0,667 & 0,571 \\
\hline $\begin{array}{c}\text { Competence } \\
\text { Ability Test }\end{array}$ & 0,210 & 0,222 & 0,286 \\
\hline Interest & 0,158 & 0,111 & 0,143 \\
\hline
\end{tabular}

TABLE VI. CALCUlation TeChNiQue Division of ElEMENTS

\begin{tabular}{|c|c|c|}
\hline$=1,000 / 1.583=0,632$ & $=3,000 / 4,500=0,667$ & $\begin{array}{c}=4,000 / 7000= \\
0,571\end{array}$ \\
\hline$=0,333 / 1.583=0,210$ & $=1,000 / 4,500=0,222$ & $\begin{array}{c}=2,000 / 7000= \\
0,286\end{array}$ \\
\hline$=0,250 / 1.583=0,158$ & $=0,500 / 4,500=0,111$ & $\begin{array}{c}=1,000 / 7000= \\
0,143\end{array}$ \\
\hline
\end{tabular}

3) Calculating Egien Vector normalization by adding each line is then divided by the number of criteria in this case is the number of criteria 3.

TABLE VII. EIGEN VECTOR NORMALIZATION

\begin{tabular}{|l|l|l|l|l|l|}
\hline Criteria & $\begin{array}{l}\text { Values } \\
\text { Specifi } \\
\mathbf{c} \\
\text { Subject } \\
\text { s }\end{array}$ & $\begin{array}{l}\text { Compete } \\
\text { nce } \\
\text { Ability } \\
\text { Test }\end{array}$ & $\begin{array}{l}\text { Interes } \\
\mathbf{t}\end{array}$ & $\begin{array}{l}\text { Numb } \\
\text { er of } \\
\text { Rows }\end{array}$ & $\begin{array}{l}\text { Eigen Vector } \\
\text { Normalizatio } \\
\text { n }\end{array}$ \\
\hline $\begin{array}{l}\text { Values } \\
\text { Specific } \\
\text { Subjects }\end{array}$ & 0.632 & 0,667 & 0,571 & 1,870 & 0,623 \\
\hline $\begin{array}{l}\text { Compet } \\
\text { ence } \\
\text { Ability } \\
\text { Test }\end{array}$ & 0,210 & 0,222 & 0,286 & 0,718 & 0,239 \\
\hline Interest & 0,158 & 0,111 & 0,143 & 0,412 & 0,137 \\
\hline
\end{tabular}

4) Calculating the ratio of consistency to determine whether comparative assessment is consistent with the way:

a)Calculating Eigen values Maximum ( $\alpha$ mak). $\alpha m a k=(1,583 \times 0,623)+(4,500 \times 0,239)+(7,000 \times 0,137)=$ 3,021

$$
\begin{aligned}
& \text { b) Calculating Consistency Index ( CI ). } \\
& \mathrm{CI}=(3,021-3) / 3-1=0,011 \\
& \text { c) Calculating Consistency Ratio }(C R) \text {. } \\
& \mathrm{CR}=0,011 / 0,58=0,019
\end{aligned}
$$

Because $\mathrm{CR}<0.100$ means the weighting preferences are inconsistent or invalid.

5) Determine the comparison matrix for sub-criteria; in this case the same value will be used mainly by the matrix comparison criteria.

a) Sub Criteria Values Specific Subjects.
TABLE VIII. COMParison MATRIX SUB CRITERIA VALUE SPECIFIC SUBJECTS

\begin{tabular}{|c|c|c|c|c|c|}
\hline Criteria & $\begin{array}{c}\text { Very } \\
\text { Good }\end{array}$ & Good & $\begin{array}{c}\text { Undeci } \\
\text { ded }\end{array}$ & $\begin{array}{c}\text { Numbe } \\
\text { r of } \\
\text { Rows }\end{array}$ & $\begin{array}{c}\text { Eigen } \\
\text { Vector } \\
\text { Normalizati } \\
\text { on }\end{array}$ \\
\hline $\begin{array}{c}\text { Very } \\
\text { Good }\end{array}$ & 0.632 & 0,667 & 0,571 & 1,870 & 0,623 \\
\hline Good & 0,210 & 0,222 & 0,286 & 0,718 & 0,239 \\
\hline $\begin{array}{c}\text { Undecid } \\
\text { ed }\end{array}$ & 0,158 & 0,111 & 0,143 & 0,412 & 0,137 \\
\hline
\end{tabular}

b) Sub Criteria Competence Ability Test

TABLE IX. COMPARISON OF SUB CRITERIA MATRIX COMPETENCE ABILITY TEST

\begin{tabular}{|c|c|c|c|c|c|}
\hline Criteria & $\begin{array}{c}\text { Very } \\
\text { Good }\end{array}$ & Good & $\begin{array}{c}\text { Undecid } \\
\text { ed }\end{array}$ & $\begin{array}{c}\text { Numbe } \\
\text { r of } \\
\text { Rows }\end{array}$ & $\begin{array}{c}\text { Eigen } \\
\text { Vector } \\
\text { Normalizat } \\
\text { ion }\end{array}$ \\
\hline $\begin{array}{c}\text { Very } \\
\text { Good }\end{array}$ & 0.632 & 0,667 & 0,571 & 1,870 & 0,623 \\
\hline Good & 0,210 & 0,222 & 0,286 & 0,718 & 0,239 \\
\hline $\begin{array}{c}\text { Undecid } \\
\text { ed }\end{array}$ & 0,158 & 0,111 & 0,143 & 0,412 & 0,137 \\
\hline
\end{tabular}

c) Sub Criteria Interests

TABLE X. COMPARISON OF SUB-CRITERIA MATRIX INTEREST

\begin{tabular}{|c|c|c|c|c|c|}
\hline Criteria & $\begin{array}{c}\text { Very } \\
\text { Good }\end{array}$ & Good & $\begin{array}{c}\text { Undeci } \\
\text { ded }\end{array}$ & $\begin{array}{c}\text { Numbe } \\
\text { rof } \\
\text { Rows }\end{array}$ & $\begin{array}{c}\text { Eigen } \\
\text { Vector } \\
\text { Normalizati } \\
\text { on }\end{array}$ \\
\hline $\begin{array}{c}\text { Very } \\
\text { Good }\end{array}$ & 0.632 & 0,667 & 0,571 & 1,870 & 0,623 \\
\hline Good & 0,210 & 0,222 & 0,286 & 0,718 & 0,239 \\
\hline $\begin{array}{c}\text { Undecid } \\
\text { ed }\end{array}$ & 0,158 & 0,111 & 0,143 & 0,412 & 0,137 \\
\hline
\end{tabular}

6) Determine the ranking of alternatives by calculating eigen vectors for each criteria and sub-criteria.

TABLE XI. DETERMINATION OF Alternative RANKING

\begin{tabular}{|l|l|l|l|l|}
\hline Criteria & $\begin{array}{l}\text { Values } \\
\text { Specific } \\
\text { Subjects }\end{array}$ & $\begin{array}{l}\text { Competence } \\
\text { Ability Test }\end{array}$ & Interest & Result \\
\hline $\begin{array}{l}\text { Computer } \\
\text { Technique } \\
\text { Network }\end{array}$ & 2 & 1 & 1 & 0,383 \\
\hline $\begin{array}{l}\text { Multimedia } \\
\text { Technique } \\
\text { Network }\end{array}$ & 3 & 2 & 3 & 0,161 \\
\hline $\begin{array}{l}\text { Information } \\
\text { Technology }\end{array}$ & 1 & 2 & 2 & 0,478 \\
\hline
\end{tabular}

In this case, the student will be taken one person that will be made sample of the research in computer engineering courses Amikom Mataram on behalf of students Didik Saputra with the students' number: 13.TK.198.

The data obtained from the weighting was as follows: 
a) Subjects specific value for Competence Computer Technique Network = 2 (Good ), Value Competence Multimedia Technique Network = 1.6 (Undecided), and Information Technology $=3$ (Very Good).

b) Competence Ability Test for competence Computer Technique Network = 1 (Very Good), Multimedia Technique Network $=2($ Good $)$ and Information Technology $=2($ Good $)$.

c) Interest for competence Computer Technique Network = 1 (Very Good), Multimedia Technique Network = 3 (undecided) and Information Technology $=2($ Good $)$.

To fill in the results in Table 11, multiplication was made between vector invitation criterion vector value sub-criteria, and adding each of the multiplication results.

- Computer Technique Network $=(0,623 \mathrm{x}$ $0,239)+(0,239 \times 0,623)+(0,137 \times 0,623)=0,149+$ $0,149+0,085=0,383$

- Multimedia technique Network $=(0,623 \mathrm{x}$ $0,137)+(0,239 \times 0,239)+(0,137 \times 0,137)=0,085+$ $0,057+0,019=0,161$

- Information Technology $=(0,623 \times 0,623)+(0,239 \times$ $0,239)+(0,137 \times 0,239)=0,388+0,057+0,033=$ 0,478

C. Results

The result of the study by using Analytical Hierarchy Process (AHP) was implemented into Expert Choice 11 software to determine the level of accuracy in decision making. The results obtained from Expert Choice 11 software as in figure below:

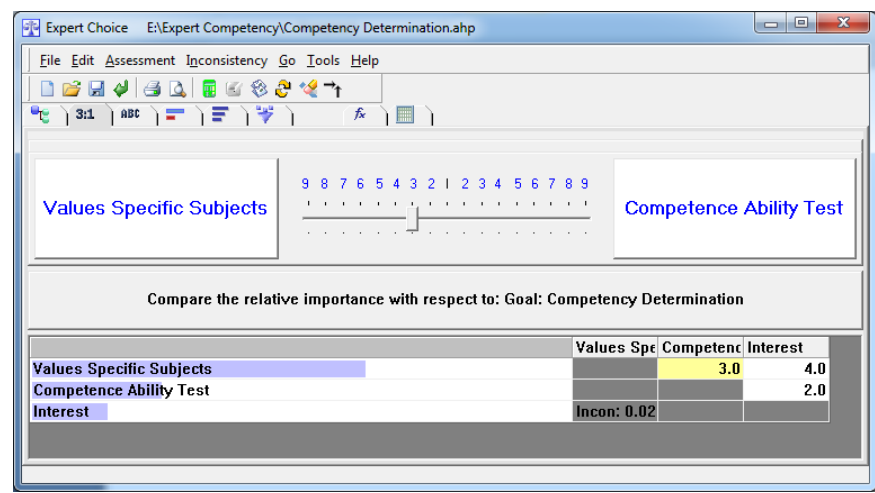

Fig. 3. Pair-wise Comparison

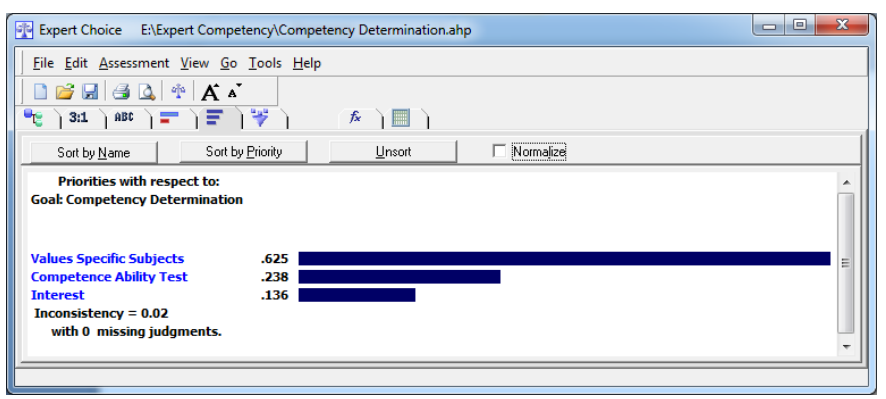

Fig. 4. Comparison Priority Competence

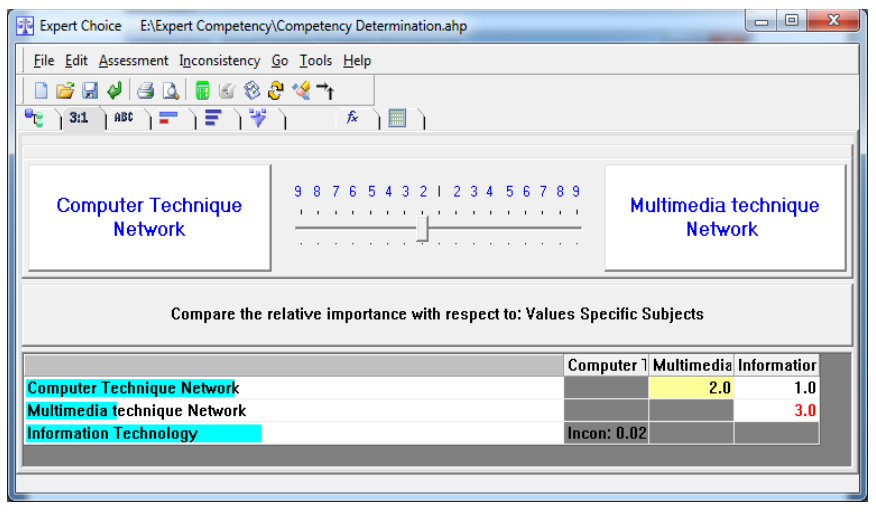

Fig. 5. Based on the Pair-wise Comparison Value Specific Subjects

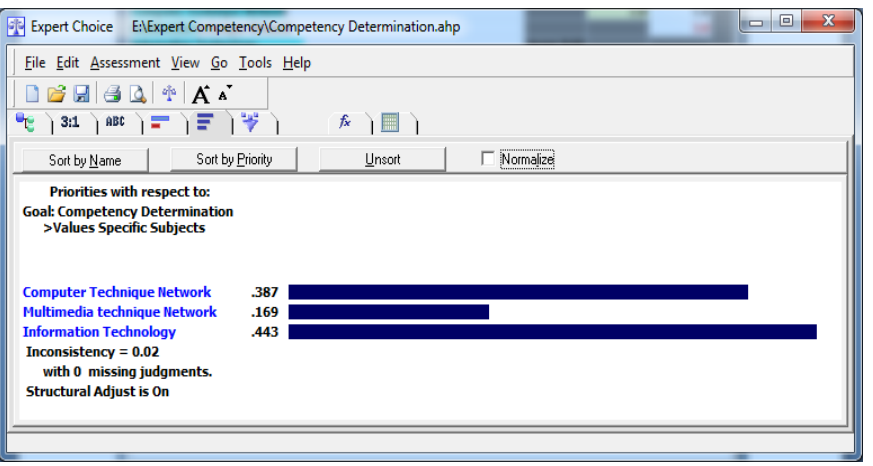

Fig. 6. Priority Pair-wise Comparison Based Value Specific Subjects

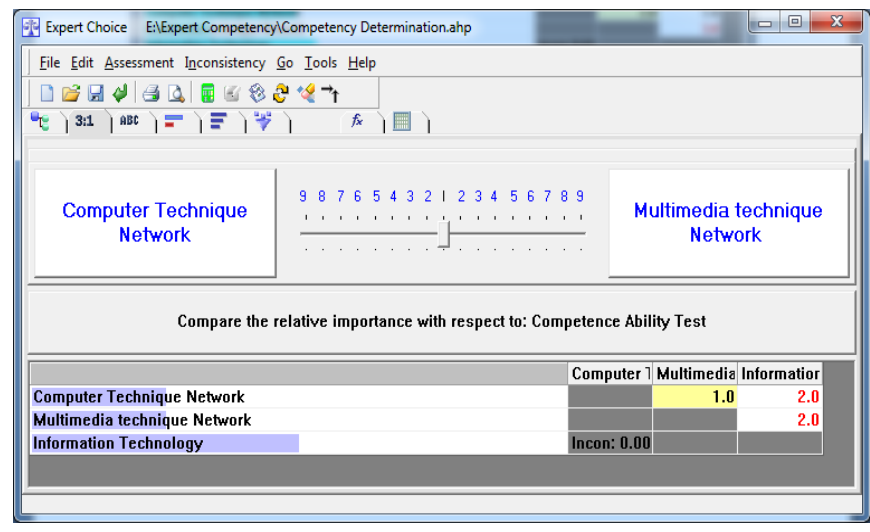

Fig. 7. Based on the Pair-wise Comparison Competence Ability Test

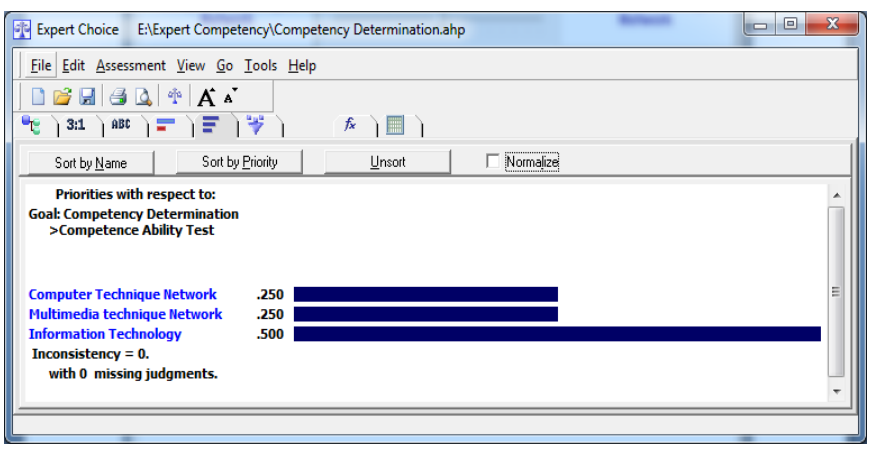

Fig. 8. Priority Pair-wise Comparison Based on Competence Ability Test 


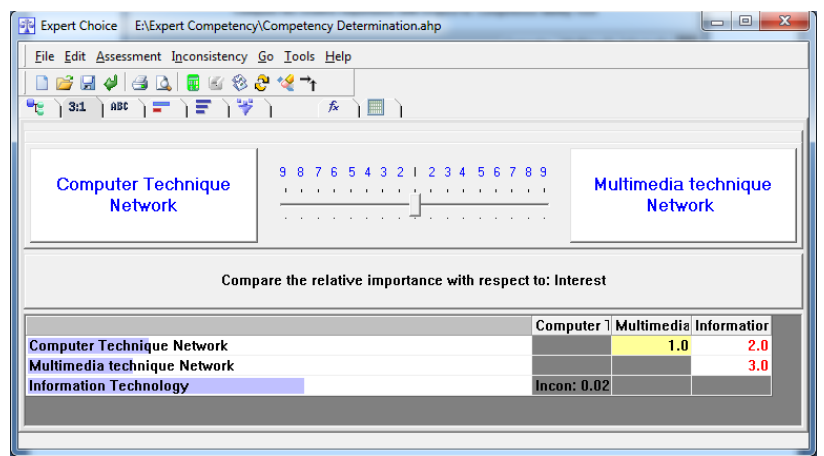

Fig. 9. Pairwise Comparison By Interest

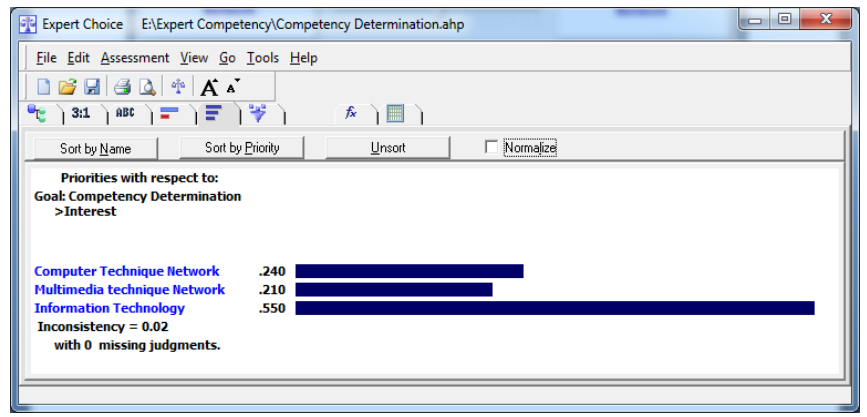

Fig. 10. Based on the Pair-wise Comparison Priority Interest

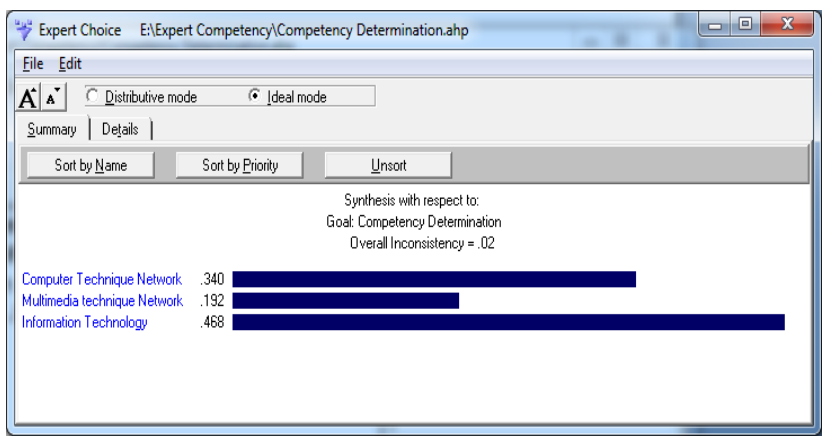

Fig. 11. Comparison of Competence Final Results

\section{CONCLUSION}

Based on the competence election on computer engineering, courses at the Academy of Information Management and Computer Mataram used Hierarchy Process Analytical methods, Expert Choice and 11 software with the value of certain courses, competence test ability, and students' interests. It can be concluded that the students do not find it difficult to choose his or her major.

REFERENCES

[1] Industri, J. T., Teknik, F., \& Andalas, U. (2015). ANALISIS PEMILIHAN PEMASOK DENGAN METODE ANALITYCAL HIERARCHY PROCESS, 14(1), 50-65.

[2] Lemantara, J., Setiawan, N.A. \& Aji, M.N., 2013. Rancang Bangun Sistem Pendukung Keputusan Pemilihan Mahasiswa Berprestasi Menggunakan Metode AHP dan Promethee. , 2(4), pp.20-28

[3] Metode, M., \& Ahp, F. (2011). Sistem Pendukung Keputusan (Spk) Pemilihan Karyawan Terbaik Menggunakan Metode Fuzzy Ahp (FAhp), 2011(Snati), 17-18.

[4] Nurmianto, E., Siswanto, N., \& Sapuwan, S. (2006). PERANCANGAN PENILAIAN KINERJA KARYAWAN DENGAN METODE ANALYTICAL HIERARCHY PROCESS (Studi Kasus di Sub Dinas Pengairan, Dinas Pekerjaan Umum, Kota Probolinggo). Jurnal Teknik Industri, 8(1), 40-53..

[5] Pangkalpinang, L., \& Magdalena, H. (2012). Sistem Pendukung Keputusan Untuk Menentukan Mahasiswa Lulusan Terbaik Di Perguruan Tinggi ( Studi Kasus Stmik Atma, 2012(Sentika).

[6] Process, A.H. \& Alam, W., 2014. Aplikasi pendukung keputusan dalam penentuan objek wisata alam menggunakan metode ahp berbasis android. , 1(1).

[7] Putra, D.S. et al., Dan Sig Dalam Menentukan Lokasi Pembangunan Cabang ( Decision Support System Using Ahp and Gis in Determining the. , pp.1-6.

[8] Saragih, S. H. (2013). PENERAPAN METODE ANALITYCAL HIERARCHY PROCESS (AHP) PADA SISTEM PENDUKUNG KEPUTUSAN PEMILIHAN LAPTOP, 82-88.

[9] Sukoharjo, P. R. (2012). Sistem pendukung keputusan dengan metode, 2(1), 1-15.

[10] Supriyono, Arya Wardhana Wisnu, S. (2007). sistem pemilihan pejabat struktural Dengan Metode AHP. Seminar Nasional III SDM Teknologi Nuklir Yogyakarta, 21-22 November 2007 ISSN 1978-0176, (November), 21-22.

[11] Suryadi, Kadarsyah dan Ramdhani, M. Ali (1998), Sistem Pendukung Keputusan Suatu Wacana Struktural Idealisasi \& Implementasi Konsep Pengambil an Keput usan, Remaja Rosdakarya, Bandung. 